\title{
К ВОПРОСУ СОВЕРШЕНСТВОВАНИЯ ФИНАНСИРОВАНИЯ НАУЧНЫХ ПРОЕКТОВ В РОССИЙСКОЙ ФЕДЕРАЦИИ
}

\section{THE QUESTION OF IMPROVING THE FUNDING OF SCIENTIFIC PROJECTS IN THE RUSSIAN FEDERATION}

\begin{abstract}
At present, the problems of funding research activities and taxation of research grants are inextricably linked. Science financing, according to the leadership of our country, is of paramount importance and must be accompanied by breakthrough discoveries in its various fields. At the same time, in practice, there are questions of how the grantees will receive full budget funds for scientific research. The Author in a series of articles explores the mechanism of appointment, the use of grants as well as controversial issues of their taxation and makes suggestions for improvement in this area.
\end{abstract}

Keywords: grants, grantees, taxes, RFBR, science funding

Ключевые слова: гранты, грантополучатели, налоги, РФФИ, финансирование науки

\section{Введение}

В современном мире наибольшее внимание уделяется теме финансирования научной деятельности, ибо развитие науки и наукоемких отраслей экономики, есть важная стратегическая задача нашего государства. На недавних заседаниях Совета по науке и образованию, посвященным вопросам глобальной конкурентоспособности российской науки, с докладом выступал Президент Российской Федерации Владимир Владимирович Путин. В частности, он отметил: «В науке, как в других областях мы должны добиваться настоящего прорыва. Нужно раз и навсегда отказаться от поддержки неэффективных, от устаревших, отживших подходов в организации научной деятельности и безусловно, страна ждет от науки новых решений, которые могут изменить качество жизни людей, придать мощную динамику развития России» (8 февраля 2018 года г. Новосибирск). «Это вопрос нашего существования, нашего выживания в полном смысле этого слова. Знания, технология, кадры - основа для реализации наших нацпроектов, для достижения наших стратегических целей. Нам нужны прорывные открытия и разработки. Они позволяют создать отечественную продукцию мирового уровня»- сказал он. «Мы не будем экономить на науке. Но мы должны сделать так, чтобы огромные средства привнесли отдачу для государства и общества, для развития самой науки» - добавил президент (27 ноября 2018 года г. Москва).

В том же духе 13 февраля 2019 года на 452-м заседании Совета Федерации высказалась Председатель комитета по науке, образованию и культуре Зоя Федоровна Драгункина: «Без науки, образования 
и культуры прорывное развитие страны невозможно» [www. council.gov.ru (дата доступа 12.06.2019)].

Зададимся вопросом: возможно ли эффективное финансирование научной деятельности без «прозрачного» механизма распределения бюджетной средств на назначение, выдачу и использование грантов и без устоявшейся системы налогообложения грантов на проведение научных исследований?

Разберем этот вопрос на примере конкретной ситуации. Мы с коллегами из Института государства и права РАН приняли участие в конкурсе на получение гранта от Российского фонда фундаментальных исследований и благополучно победили в нем. Наш научный проект посвящен изучению правового механизма назначения, выдачи и использования грантов в целях финансирования научно-исследовательских, опытно-конструкторских и технологических работ. Встал вопрос: а какую сумму, выделенную фондом на научные исследования, мы получим в итоге? Оказалось, что вроде бы простой вопрос, имеет несколько вариантов ответа.

Во-первых, часть средств, благодаря заключенному трехстороннему договору между грантополучателями, ведущей организацией и фондом, ведущая организация оставляет себе. Сумма это колеблется от 10 до $20 \%$, в зависимости от условий договора. Ведущая организация, не оказывая никаких услуг, не являясь работодателем по условиям данного договора, автоматически забирает себе эту часть средств, выделенную на научные исследования. А можно ли было принять участие в конкурсе группе ученых на получение гранта минуя ведущую организацию? На сайте Российского фонда фундаментальных исследований [www.rfbr.ru/rffi/ru/faq (дата доступа 12.04.2019)], я нашел однозначный ответ, что в первую очередь рассматриваются заявки научных групп, где присутствует ведущая организация. Стало понятно, что избежать трехстороннего договора не удастся и эти отчисления являются так называемым «скрытым налогом», который внедрен в систему распределения бюджетных средств, направленных на развитие научных исследований [Белявский 2017, сс. 1-22].

Во-вторых, со стороны бухгалтерской службы ведущий организации поступали недвусмысленные поползновения, уплатить с сумм, выделенных нам фондом, налог на доходы физических и лиц, и страховые взносы. Точно такие же вопросы поступали ко мне со стороны коллег, которые участвовали в своих научных проектах и не могли самостоятельно разобраться в этом вопросе.

Для начала разберемся в нормативно-правовых актах, касающихся налогообложения грантов на проведение научных исследований.

По мнению законодателя, гранты - денежные и иные средства, передаваемые безвозмездно и безвозвратно гражданами и юридическими лицами, в том числе иностранными гражданами и иностранными юридическими лицами, а также международными организациями, получившими право на предоставление грантов на территории Российской Федерации установленном Правительством Российской Федерации порядке, на осуществление конкретных научных, научно-технических программ и проектов, инновационных проектов, проведение конкретных научных исследований на условиях, предусмотренных грантодателями [Федеральный закон от 23.08.1996 № 127Ф3 (ред. От 23.05.2016) «О науке и государственной научно-технической политике» ст.2].

В Налоговом кодексе Российской Федерации (часть вторая) от 05.08.2000 № 117-Ф3 в п.6 ст.217 [Налоговый кодекс Российской Федерации (часть вторая) от 05.08.2000 № 117-Ф3 п.6 ст.217] указано, что суммы, получаемые в виде грантов (безвозмездной помощи), предоставленных для поддержки науки и образования, культуры и искусства в Российской Федерации международными, иностранными и (или) российскими организациями по перечням таких организаций, утверждаемым Правительством Российской Федерации, освобождаются от уплаты налога на доходы физических лиц (п. 6 в ред. Федерального закона от 23.03.2007 № 38-Ф3).

Постановлением Правительства Российской Федерации от 15 июля 2009 года № 602 утвержден перечень российских организаций, получаемые налогоплательщиками гранты (безвозмездная помощь) которых, предоставленные для поддержки науки, образования, культуры и искусства в Российской Федерации, не подлежат налогообложению, где под пунктом 11 значится Российский фонд фундаментальных исследований, г. Москва.

Изучив весь этот перечень нормативных актов, можно дать однозначный ответ, что вопросы налогообложения грантов на проведение научных исследований однозначно трактуются в пользу грантополучателей-физических лиц и несмотря на это, на практике возникают спорные вопросы об их применении. 
Судебная практика по налогообложению грантов на научные исследования, наоборот, оказалась очень скудна. Несмотря на это, письма Департамента налоговой и таможенной политики Минфина РФ по данной тематике выходили с завидным постоянством. Вот выдержка одного из последних их ответов на письма граждан по данному вопросу: «Так, в соответствии с пунктом статьи 6 статьи 217 Налогового кодекса Российской Федерации освобождаются от обложения налогом на доходы физических лиц суммы, получаемые налогоплательщиками в виде грантов (безвозмездной помощи), предоставленных для поддержки науки и образования, культуры и искусства в российской Федерации международными, иностранными и (или) российскими организациями по перечням таких организаций, утверждаемым Правительством Российской Федерации.

Российский фонд фундаментальных исследований включен в Перечень российских организаций, утвержденный постановлением Правительства Российской Федерации от 15.07.2009 №602, фанты (безвозмездная помощь) которых, предоставленные налогоплательщикам для поддержки науки, образования, культуры и искусства в Российской Федерации, не полежат обложению налогом на доходы физических лиц» [Письмо Департамента налоговой и таможенной политики Минфина России от 28 марта 2018 г. № 03-04-06/19786].

О чем это говорит? Что достаточно прозрачная норма права трактуется сторонами-участниками договора самостоятельно, без учета реалий.

В этой же связи, я обнаружил письмо Российской академии наук от 3 мая 2011 года № 10116-1429/95, где четко выражена позиция главного научного заведения нашей страны: «Исходя из изложенного, средства на оплату труда, выплачиваемые из сумм грантов по согласованию с руководителем проекта научным работникам, принимающим участие в проектах РФФИ, освобождаются от налогообложения налогом на доходы физических лиц со дня утверждения перечня российских организаций вышеуказанным Постановлением Правительства Российской Федерации. Возврат налогоплательщикам сумм излишне удержанного налога на доходы физических лиц производится исходя из положений ст.ст.78 и 231.2 Налогового кодекса Российской Федерации».
Надо отдать должное позиции самого Российского фонда фундаментальных исследований по вопросу уплаты налога на доходы физических лиц и страховых взносов. На своем сайте он четко объясняет своё мнение по данному вопросу: «В соответствии с действующим законодательством, п.6 Ст.217 НК РФ грант, полученный физическим лицом (физическими лицами) освобождается от обложения налогом на доходы физических ли Полагаем, что выплаты страховых взносов, если они осуществляются Организацией в рамках отношений, оформленных документами Фонда, не могут быть признаны обоснованными» [www.rfbr.ru/rffi/ru/faq (дата доступа 12.06.2019)].

В этой же связи, не лучшим образом обстоит дело с так называемыми «хозяйственными договорами», которые выполняют ученые-исследователи в своих научных институтах для поддержания своего финансового благополучия, отвлекаясь от первостепенных задач. Это дополнительный способ заработка для любого российского ученого, приводит к еще более глубокому секвестированию получаемой на руки суммы. До 40 процентов от сумм, выплаченных на его реализацию, уходит работодателю, а с оставшихся средств еще выплачиваются подоходный налог, страховые взносы и.т.п.

\section{Заключение}

Что мы имеем в итоге? Благодаря нынешней системе налогообложения грантов на проведение научных исследований, мы получаем неэффективное распределение бюджетных средств, направленных на развитие научной мысли в нашей стране. [Курбатова 2015, сc. 141-149]. По скромным подсчетам, грантополучатель-физическое лицо может недополучать более половины средств из этой сумм. Бюджетные средства, направленные на науку, прокрутившись на счетах организаций, снова и снова возвращаются в бюджет, так и не дойдя до конечного пользователя.

Нынешнее положение дел, говорит о том, без реформирования нынешней системы налогообложения и механизма распределения бюджетной средств на назначение, выдачу и использование грантов в целях финансирования научно-исследовательских, опытно-конструкторских и технологических работ, мы не можем ожидать новых прорывных научных проектов, которых так ждет наше государство. 


\section{Библиография}

Алфимов М.В. (2007), РАН и РФФИ - разными путями $\kappa$ общей иели, „Наука. Инновации. Образование” no 1.

Бабина К.И. (2014), Грант как один из способов финансирования научных учреждений: особенности, проблемы, перспективы, „Вестник Саратовского государственного социально-экономического университета" no. 13.

Белявский О.В. (2017), Проблемы правового регулирования грантовой поддержки фундаментальных научных исследований в современном законодательстве Российской Федераиии, РФФИ, Москва.

Бердашкевич А.П., Булаев Н.И. (2005), Налоговое и бюджетное регулирование инновачионной, научной и образовательной деятельности, Интерконтакт Наука, Москва.

Козлова Л.А. (2007), Государственная грантовая поддержка в общественных науках, „Наука. Инновации. Образование” nо. 56.

Курбатова С.С. (2015), Правовое регулирование грантов в системе расходов бюджета, „Закон. 2015” по. 3.

Провалинский Д. И. (2017), Гранты - пути развития: отечественный и зарубежный опыт, „Вестник Костромского государственного университета" no. 2.

Совершенствование финансового обеспечения фундаментальных научных исследований в Российской Федерации [online], www.dissercat.com/content/ sovershenstvovanie-finansovogo-obespecheniyafundamentalnykh-nauchnykh-issledovanii-v-rossii, дата доступа 12.06.2019.

Соколова С.А. (2015), Грант в системе бюджетного субсидирования „Петербургский юрист” по. 1.

Цыганов С.А., Рудцкая Е.Р., Хрусталев Е.Ю. (2012), Совериенствование конкурсных механизмов поддержки и финансирования научной, научно-технической и инновационной деятельности, „Национальные интересы: приоритеты и безопасность” no. 11 (152).

\section{Список правовых актов}

Гражданский кодекс Российской Федерации (часть первая) от 30 ноября 1994 года (№ 51-ФЗ // СЗ РФ. 1994. № 32. Ст. 3301).

Гражданский кодекс Российской Федерации (часть вторая) от 26 января 1996 года (№ 14-ФЗ // СЗ РФ. 1996. №5. Ст. 410).

Федеральный закон от 23 августа 1996 года № 127-Ф3 «О науке и государственной научно-технической политике» // СЗ РФ. 1996. (№ 35. Ст. 4137).

Бюджетный Кодекс Российской Федерации от 31 июля 1998 года (№ 145-Ф3 // СЗ РФ. 1998. № 31. Ст. 3823).

Налоговый кодекс Российской Федерации (часть вторая) от 5 августа 2000 года (№ 117-Ф3 // СЗ РФ. 2000. № 32. Ст. 3340).

Федеральный закон от 2 июля 2013 года (№ 181-Ф3 «О внесении изменений в статьи 78 и 78.1 Бюджетного кодекса Российской Федерации в части предоставления грантов» // СЗ РФ. 2013. № 27. Ст. 3473).

Постановление Правительства РФ от 24.07.2002 (№554 (ред. от 27.04.2005) «О грантах Президента Российской Федерации для поддержки молодых российских ученых - кандидатов наук и их научных руководителей» // СЗ РФ. 2002. № 30. Ст. 3056).

\section{Author bibliography}

Oleg Novikov Viktorovich - scientific researcher in the sector of financial tax, banking and competition law at the Russian Academy of Sciences (Russia). 